\title{
Benign pneumatosis intestinalis with pneumoperitoneum and typhlitis: side-effects of drug or disease induced immunosuppression
}

\author{
Naomi Jane Wright, ${ }^{1}$ Tom Wiggins, ${ }^{1}$ Benjamin Michael Stubbs, ${ }^{2}$ Alec Engledow ${ }^{2}$ \\ ${ }^{1}$ Department of General Surgery, University College Hospital, London, UK; \\ ${ }^{2}$ Department of Colorectal Surgery, University College Hospital, London, UK
}

Correspondence to Mr Tom Wiggins, thomas.wiggins@hotmail.co.uk

\section{DESCRIPTION}

This 42-year old woman had been newly diagnosed with Hodgkin's lymphoma with a background of HIV, hepatitis $\mathrm{C}$ and recent tuberculosis (TB) meningitis. She was on HIV antiretrovirals, TB chemotherapy and prednisolone. A routine prechemotherapy chest $\mathrm{x}$-ray showed free air under the diaphragm. CT showed extensive intramural air involving the large bowel and terminal ileum, air in the mesocolon and small bowel mesentery and free air

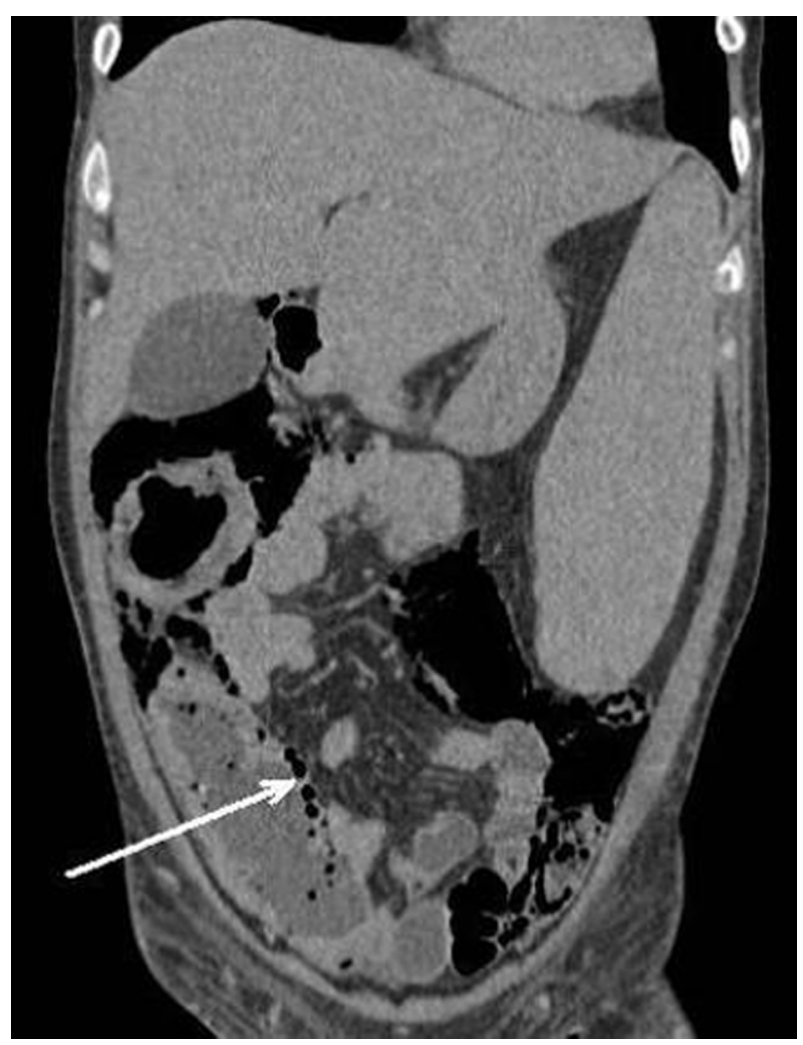

Figure 1 Coronal CT abdomen demonstrating pneumotosis intestinalis (white arrow) with pneumoperitoneum. (figure 1). At the time of this imaging she was asymptomatic, however, a week later she developed neutropenic sepsis (white blood cell count 0.39 , neutrophil count 0.09 ) with a right pleural effusion and right-sided abdominal tenderness. Repeat CT showed similar findings but with a thick-walled caecum and pericaecal fat stranding suggestive of typhlitis. She was managed conservatively and is now symptom free. Pneumatosis intestinalis, especially in the presence of pneumoperitoneum, is a cause for urgent surgical review. Although this radiological finding can be associated with bowel ischaemia, infarction and perforation requiring immediate surgical intervention, the majority of cases (85\%) are benign and can be managed conservatively. ${ }^{1}$ Documented causes include: chemotherapy, steroids, AIDS, organ transplant, leukaemia, chronic obstructive pulmonary disease, infective enteritis, coeliac disease, connective tissue disorders and amyloidosis. ${ }^{1} 2$ Typhlitis is another condition associated with drug or disease induced immunosuppression and is characterised by life-threatening neutropenic enterocolitis and transmural inflammation of the caecum, often with pneumatosis. ${ }^{3}$ Signs and symptoms mimic those of appendicitis. There are no randomised-controlled trials comparing conservative with surgical management of this condition; treatment must be individualised depending on clinical evidence of perforation or deterioration despite optimal medical management. ${ }^{3}$

Acknowledgements Dr Darren Boone, SpR radiology for providing expert help on selecting the best image.

Competing interests None.

Patient consent Obtained.

\section{REFERENCES}

1. Khalil PN, Huber-Wagner S, Ladurner R, et al. Natural history, clinical pattern, and surgical considerations of pneumatosis intestinalis. Eur $J$ Med Res 2009;14:231-9

2. Ho LM, Paulson EK, Thompson WM. Pneumatosis intestinalis in the adult: benign to life-threatening causes. AJR Am J Roentgenol 2007;188:1604-13.

3. Davila ML. Neutropenic enterocolitis. Curr Opin Gastroenterol 2006;22:44-7. 


\section{BMJ Case Reports}

This pdf has been created automatically from the final edited text and images.

Copyright 2011 BMJ Publishing Group. All rights reserved. For permission to reuse any of this content visit http://group.bmj.com/group/rights-licensing/permissions.

BMJ Case Report Fellows may re-use this article for personal use and teaching without any further permission.

Please cite this article as follows (you will need to access the article online to obtain the date of publication).

Wright NJ, Wiggins T, Stubbs BM, Engledow A. Benign pneumatosis intestinalis with pneumoperitoneum and typhlitis: side-effects of drug or disease induced immunosuppression. BMJ Case Reports 2011;10.1136/bcr.07.2011.4518, date of publication

Become a Fellow of BMJ Case Reports today and you can:

- Submit as many cases as you like

- Enjoy fast sympathetic peer review and rapid publication of accepted articles

- Access all the published articles

- Re-use any of the published material for personal use and teaching without further permission

For information on Institutional Fellowships contact consortiasales@bmjgroup.com

Visit casereports.bmj.com for more articles like this and to become a Fellow 